\title{
The Incorporation of Specialised Data in Lexicographical Meaning Explanations: A Discussion Based on Sports and Fitness Terms*
}

\author{
Heidi Agerbo, Centre for Lexicography, Department of \\ Business Communication, School of Business and Social Sciences, \\ Aarhus University, Aarhus, Denmark (heap@bcom.au.dk)
}

\begin{abstract}
There is a problematic treatment of field specific words in both general language dictionaries as well as specialised dictionaries, which in this paper is exemplified using the sports and fitness subject fields as the point of departure and focusing on meaning explanations. Particularly the treatment in general dictionaries in many cases results in inadequate solutions that cannot sufficiently accommodate the dictionary users' needs if we consider these from the viewpoint of the function theory, according to which a dictionary is designed to help a specific user type with a punctual information need that has occurred in a specific type of extra-lexicographical user situation. In this study, a total of 44 general and specialised information tools in English and Danish were analysed. The first part of the investigation involved an analysis of the introductory matter to determine the intended user situation(s) and user(s) of each tool. In the second part, a selected number of sports and/or fitness related lemmata in the dictionaries were analysed. These test words and their meaning explanations were in each dictionary compared to the dictionary's mentioned user situation(s) and user(s). Based on this comparison, a number of identified problems with the meaning explanations are discussed, and a set of principles for best practice when producing meaning explanations of specialised terms is suggested. The study revealed that quite a number of these information tools either do not clearly specify their functions or, to some extent, cannot live up to their intended functions. Some additional interesting findings were also made as some of the dictionaries either explicitly or implicitly are designed with operative and interpretative functions, which are functions that have yet not been fully incorporated into lexicographical theory. The overall findings from the study have led to a suggested function-based definition of meaning explanations to be applied in all types of information tools.
\end{abstract}

Keywords: MEANING EXPLANATION, FUNCTION THEORY, INTRODUCTORY MATTER, USER TYPE, USER SITUATION, GENERAL DICTIONARY, SPECIALISED DICTIONARY, SPORT, FITNESS

* This article was presented as a paper at the Twenty-first Annual International Conference of the African Association for Lexicography (AFRILEX), which was hosted by the Xitsonga and Sesotho sa Leboa National Lexicography Units, Tzaneen, South Africa, 4-6 July 2016. 
Opsomming: Die opname van gespesialiseerde inligting in leksikografiese betekenisomskrywings. 'n Bespreking gebaseer op sportsoorte en fiksheidsterme. Vakspesifieke woorde se hantering is problematies in sowel algemene as gespesialiseerde woordeboeke. In hierdie artikel word dit toegelig met die vakgebiede sport en fiksheid as vertrekpunt en word daar gefokus op betekenisomskrywing. In baie gevalle is dit veral die hantering in algemene woordeboeke wat uitloop op onvoldoende oplossings wat nie voldoende voorsiening maak vir die gebruiker se behoeftes as ons dit beskou vanuit die hoek van die funksieteorie nie, waarvolgens 'n woordeboek ontwerp word om 'n spesifieke soort gebruiker te help met 'n presiese inligtingsbehoefte wat spruit uit ' $n$ spesifieke soort buiteleksikografiese gebruikersituasie. Tydens hierdie studie is 'n totaal van 44 algemene en gespesialiseerde inligtingshulpmiddels in Engels en Deens ontleed. Die eerste deel van die ondersoek het ingehou dat 'n ontleding van die inleidende gedeelte gedoen is om die bedoelde gebruikersituasie(s) en gebruikers van elke hulpmiddel te bepaal. In die tweede gedeelte is 'n uitgesoekte aantal lemmas wat met sportsoorte en/of fiksheid te doen het in die woordeboeke ontleed. Hierdie woorde wat deel vorm van die toets en hulle betekenisomskrywings in elke woordeboek is vergelyk met die gebruikersituasie(s) en gebruiker(s) wat in die woordeboek genoem word. Op grond van hierdie vergelyking word 'n aantal probleme bespreek wat met die betekenisomskrywings geïdentifiseer is en ' $n$ stel beginsels vir die beste praktyk word voorgestel vir die saamstel van betekenisomskrywings in die geval van gespesialiseerde terme. Die studie het getoon dat 'n groot aantal van hierdie inligtingshulpmiddels òf nie hulle funksies duidelik spesifiseer nie, òf in sekere mate nie heeltemal aan hulle bedoelde funksies voldoen nie. Bykomende interessante gevolgtrekkings is ook gemaak, aangesien party woordeboeke eksplisiet of implisiet ontwerp is met operatiewe en verklarende funksies, funksies wat nog nie volledig opgeneem is in die leksikografiese teorie nie. Die oorhoofse bevindings uit hierdie studie het gelei tot 'n voorgestelde funksie-gebaseerde definisie van betekenisomskrywings wat toegepas kan word op alle tipes inligtingshulpmiddels.

Sleutelwoorde: BETEKENISOMSKRYWING, FUNKSIETEORIE, INLEIDENDE GEDEELTE, SOORT GEBRUIKER, GEBRUIKERSITUASIE, ALGEMENE WOORDEBOEK, GESPESIALISEERDE WOORDEBOEK, SPORT, FIKSHEID

\section{Introduction}

The soul of a dictionary, however, is the quality of its definitions

$$
\text { Morris (1985: 6) }
$$

As this quote shows, many lexicographers and dictionary users consider the definition (or meaning explanation, as will be the term applied throughout this paper) the most important part of a dictionary. The focus of the study presented in this paper was to determine the usefulness of the meaning explanations of sports and fitness related terms provided in a number of Danish and English general and specialised dictionaries. The term usefulness is here defined on the basis of the function, i.e. whether the explanations satisfy the intended user type who has a specific information need in the intended extra-lexicographical user situation as expressed in the function theory; see e.g. Bergenholtz and Tarp (2003) and Tarp (2008a). Many lexicographers today will agree 
with the statement that a dictionary should be produced with a specific user type as the point of departure, cf. Diab (1990: 21-51) and Nesi (2013), who both comment on the development of the user-oriented focus in lexicography. However, proponents of the function theory argue that the genuine purpose of a dictionary first and foremost depends on its function, thus, all data types should be incorporated into and presented in an information tool based on their relevance according to both the intended user situation and intended user (Nielsen and Almind 2011: 154). In the study presented in this paper, the areas of sport and fitness are used to form a small sample for investigating the usefulness of meaning explanations of terms in both general and specialised information tools.

\section{Analysis of information tools}

The types of information tools chosen for the current investigation can be divided into three types: general dictionaries, multi-field dictionaries (sports dictionaries) and single-field dictionaries (e.g. tennis and martial arts dictionaries). In addition, dictionaries related to sports and fitness, e.g. a dictionary on diet and exercise and a dictionary on sports injuries, were included. Some of the general dictionaries were chosen based on their online availability, and others were randomly chosen from their physical availability from the office shelves at the Centre for Lexicography - these amounted to 17 relevant dictionaries in total ${ }^{1}$. A search was made for multi-field and single-field dictionaries at the Danish State and University Library and bibliotek.dk, a website where you search all Danish public libraries simultaneously. This only resulted in 9 additional dictionaries. A search with Google gave access to another 2 online multifield dictionaries and 2 electronic (static) multi-field dictionaries. As it was hoped to find more information tools on sports and fitness for the analysis, a search was made at amazon.com and amazon.co.uk, which resulted in 14 additional dictionaries. Thus, a total of 44 different types of information tools (i.e. tools that contain collections of structured data and are designed in a certain way to help users solve information-related problems) were selected for the analysis, e.g. dictionaries, lexicons and glossaries ${ }^{2}$.

The test words were randomly selected from English and Danish newspaper articles in sport, a number of which were from the early 1970s and the rest from after 2000, a selection made in order to match words from old newspaper articles with old dictionaries and words from recent newspaper articles with new dictionaries. 10-15 test words were chosen from each selected sports branch, which were selected based on the author's personal experience with and knowledge about these specific sports. The early articles included: boxing, (association) football, swimming and tennis, respectively; and the later articles included: boxing, (association) football, handball, tennis, running and fitness, respectively. The reason for the difference in the selection of sports branches in the old and new newspaper articles is the changing popularity of the different 
sports. Running started to become popular in the 1970s, but in the last 5-10 years, it has become more popular than ever, which means that newspapers and magazines often write about running, and modern dictionaries will (or should) contain more running terms. Fitness became very popular around the end of the 20th century, and today the fitness industry is bigger than ever, which has entailed an increased interest for this subject in newspapers and other media. Handball did not appear in any of the searches made in the English newspapers from the 1970s, and therefore articles and tests words in swimming were selected instead. In a few of the dictionaries for which these search terms were not relevant, an analysis was made of the meaning explanations on every 30th page in the dictionary. As is clear from these descriptions, the study is not statistically valid, but instead a qualitative and exemplary study, i.e. it can highlight tendencies. The purpose of the study was not to count which test words occurred in which dictionary, but to analyse how the lemmata were described in different information tools on the same or related topics and compare these descriptions to the stated dictionary functions.

\subsection{The introductory matter}

The purpose of the analysis of the dictionary introductions - also called prefaces, introductory remarks, introductory pages, introductory guides, initial information for users, and preliminaries - was to identify the intended users and user situations since this kind of information is usually provided in this part of a dictionary, cf. Bergenholtz and Tarp (1994: 174-175). Nielsen (1990: 52) describes a simple macrostructure as one typically containing only a preface and the (alphabetical) arrangement of the lemmata, thus, according to this statement, all dictionaries will most likely contain an introduction.

The different types of users typically identified in specialised lexicography are laymen, semi-experts and experts, who can be characterised according to their field-specific knowledge and also according to their language skills, cf. Bergenholtz and Tarp (1994: 17-18). Of course, when analysing the selected learner dictionaries, it will also be necessary to incorporate this type, the learner, into the user typology, and here it is possible to distinguish between three types: beginner, intermediate and advanced. In addition to this, an extra category should be added: the general user (which is, admittedly, a very broad category). It is problematic to call people who use general dictionaries laymen, as this term is seen in relation to a certain specialised field: the same person can be an expert in chemistry and a layman in linguistics, but you do not consider him an expert until he is associated with chemistry, and you do not call him a layman until he is associated with linguistics. People who use general dictionaries are not evaluated according to a specific specialised field or subfield, and therefore it would be better to call them general users (see also Béjoint 2015).

All of the general dictionaries have a communicative function, more spe- 
cifically, they are produced for reception and production. The investigated specialised dictionaries are either only for reception - none of them can be used for production - only for cognition, or both of these two functions. Especially much of the back matter in sports dictionaries supports a cognitive function. However, as will be discussed in Section 2.4, some of the dictionaries also incorporated data both in the central lists and in the outer texts that support what the function theory calls the operative and interpretative functions.

\subsubsection{The user type}

Table 1: Overview of the data on user types and user situations

\begin{tabular}{|c|c|c|c|c|}
\hline & $\begin{array}{l}\text { Is described in the intro- } \\
\text { duction/on the website }\end{array}$ & $\begin{array}{l}\text { Is only described } \\
\text { on the book } \\
\text { cover }\end{array}$ & No description & $\begin{array}{l}\text { Can be inferred } \\
\text { from the dic- } \\
\text { tionary title }\end{array}$ \\
\hline User & $\begin{array}{l}5,7,(8), 10,11,16,(18), 21 \\
23,26,27,28,29,30,31,32, \\
33,42,44\end{array}$ & $\begin{array}{l}22,24,34,35,40, \\
43\end{array}$ & $\begin{array}{l}1,2,3,4,6,9, \\
12,13,14,15 \\
17,19,20,25 \\
36,37,38,39,41\end{array}$ & $1,3,6,8$ \\
\hline Situation & $\begin{array}{l}(4), 5,7,8,9,10,11,12,13, \\
15,16,17,18,20,21,22,23, \\
25,27,28,(29), 30,31,32, \\
33,42,(43), 44\end{array}$ & $24,(35), 37,(40)$ & $\begin{array}{l}1,2,3,6,14,19 \\
26,(34), 36,38 \\
39,41\end{array}$ & \\
\hline
\end{tabular}

The numbers represent the specific dictionaries that were investigated and which are listed in the addendum

$19(+6)$ of the 44 dictionaries comment on the user in the introductions as shown in Table 1 though the amount of detail provided differs significantly as exemplified in Table 2. Some of the dictionaries do not directly describe their intended user(s) in their introductions, though their titles reveal whom these dictionaries have as their target user, e.g. Cambridge Advanced Learner's Dictionary. For those (online) dictionaries that do not mention their intended user, it may be because the producers assume that the users know the dictionaries beforehand - some of them did not even have an "about"-section, and the ones that did, primarily mentioned the incorporated data types, i.e. the content of the dictionaries. Most of the general dictionaries that do comment on their users do this only very superficially, e.g. calling them "well-informed adults" or "advanced learners", cf. Table 2. Some of the specialised dictionaries define their users as sports lovers, fanatics or fans, but the characteristics of these are not clear either. Not surprisingly, the analysis of the intended user types in the dictionaries shows a lack of clarity in the description of dictionary users. Also, some of the dictionaries are targeted towards many highly different user types, e.g. Dictionary 7, which is problematic as it is not possible to help all of them in 
the same situations; for example, a high school student and a scholar or a professional will not be satisfied by the same meaning explanation for reception, cf. Nielsen (2008: 181), who writes that "user profiles of experts and semiexperts show that these user groups have factual and linguistic competences different from those of laypersons and therefore have different needs." Another problematic issue was identified in Dictionary 44, in which the authors in the introduction write that "[w]hile there are many textbooks for the sports medicine and exercise health professional, there is a huge demand for information on these topics by the general public. It is to fill this need that we have written ...", but on the back cover (probably written by the publisher or marketing staff) it states that the book is "[e]qually valuable on the bookshelves at home for family use or at the clinics of sport and health professionals", i.e. the identification of the intended user is not the same when comparing the introduction and the back cover of the book.

Table 2: Examples of user descriptions in the investigated dictionaries

\begin{tabular}{|c|c|c|c|}
\hline Dictionary & $\begin{array}{l}\text { Dictionary type } \\
\mathrm{G}=\text { general } \\
\mathrm{S}=\text { specialised }\end{array}$ & User description & User type \\
\hline \multirow[t]{4}{*}{7} & \multirow[t]{4}{*}{ G } & \multirow{4}{*}{$\begin{array}{l}\text { This edition has been prepared with a constant regard } \\
\text { for the needs of the high school and college student, the } \\
\text { technician, and the periodical reader, as well as of the } \\
\text { scholar and professional. }\end{array}$} & General user \\
\hline & & & Layman \\
\hline & & & Semi-expert \\
\hline & & & Expert \\
\hline 10 & G & The well-informed contemporary adult. & General user \\
\hline \multirow[t]{2}{*}{11} & \multirow[t]{2}{*}{ G } & \multirow[t]{2}{*}{ Intermediate and advanced learners of English. } & $\begin{array}{l}\text { Intermediate } \\
\text { learner }\end{array}$ \\
\hline & & & $\begin{array}{l}\text { Advanced } \\
\text { Learner }\end{array}$ \\
\hline 23 & $S$ & $\begin{array}{l}\text { There is nothing in this book for the expert on any par- } \\
\text { ticular sport or game. There are no new facts. All that it } \\
\text { contains is, so to speak, common knowledge. However, } \\
\text { someone who knows little or nothing about, say, yacht- } \\
\text { ing or fox-hunting or shatranj or skat, and who wishes to } \\
\text { find out some basic facts, will, I hope, find it serviceable. }\end{array}$ & Layman \\
\hline \multirow[t]{4}{*}{26} & \multirow[t]{4}{*}{$S$} & \multirow{4}{*}{$\begin{array}{l}\text { It will be of particular help to health and fitness trainers, } \\
\text { students of PE, coaches, and athletes [...] It is also an } \\
\text { essential reference for anyone wishing to improve fit- } \\
\text { ness through exercise and healthy eating. }\end{array}$} & Layman \\
\hline & & & Semi-expert \\
\hline & & & (Beginner $\left.^{3}\right)$ \\
\hline & & & $\left(\right.$ Advanced $\left.^{4}\right)$ \\
\hline \multirow[t]{2}{*}{27} & \multirow[t]{2}{*}{$S$} & \multirow{2}{*}{$\begin{array}{l}\text { An ideal reference for students of sport and exercise } \\
\text { sciences, as well as those with a general interest in } \\
\text { health and fitness. }\end{array}$} & Layman \\
\hline & & & (Semi-expert) \\
\hline 28 & S & $\begin{array}{l}\text {... so that a reader knowing little or nothing about a } \\
\text { sport can understand the term in question. }\end{array}$ & Layman \\
\hline \multirow[t]{2}{*}{33} & \multirow[t]{2}{*}{ S } & \multirow{2}{*}{$\begin{array}{l}\text {... a must for all tennis-lovers and a valuable reference } \\
\text { book for all sporting enthusiasts. }\end{array}$} & Layman \\
\hline & & & (Semi-expert) \\
\hline 44 & $\mathrm{~S}$ & The general public & Layman \\
\hline
\end{tabular}




\subsubsection{The user situation}

The number of the investigated dictionaries that comment on the user situation is higher than the number of dictionaries that comment on the user (some of them comment on both), though the mention of user situation ranges from rather broad to more specific comments such as the dictionary having "reading and writing solutions" (Dictionary 4) and that the dictionary "is intended to help the reader understand a sport when he watches it for the first time. The descriptive section explains how it is played - as distinct from how to play it" (Dictionary 20). A few of the dictionaries do not even contain an introduction, but simply write a few pieces of information on the cover, cf. Table 1; this is especially the case for the single-field specialised dictionaries. This is an interesting observation considering the fact that Bergenholtz and Tarp (1994: 173) describe the introduction as an obligatory dictionary component. Words and phrasings such as "a reference (book)" (Dictionaries 25 and 27), "it will be of particular help" (Dictionary 26) and "it is hoped that this book will help" (Dictionary 25) do not adequately explain what kinds of tool the dictionaries are and what they intend to help the user do. It appears that the terms "reference book" and "handbook" correspond to what the function theory calls cognitive dictionaries, but because the functions in these dictionaries are not clearly described in the introductions, these examples have not been added to the "described" columns in Table 1. A number of both the general and specialised dictionaries comment on their content together with or instead of the function, e.g. Dictionary 4, though these two things should not be confused: different types of data (content) may serve the same or different functions so the dictionaries should aim to define what they want the dictionary to be used for, not only describe what they contain. As expressed by Bergenholtz and Bergenholtz (2011), "a dictionary is a tool designed to be used for one or more specific tasks. Of course, this does not mean that you cannot use it for other tasks, but then it will not be as useful." Thus, if dictionary users should be able to use a dictionary optimally, they should be told what the genuine purpose of this dictionary is.

Of course, the fact that the user situation and user are not mentioned in the introductions does not mean that these two central categories have not been applied in the production of the dictionaries - it may be because publishers do not want to restrict their clientele in the description of their product (Wingate 2002: 39). However, it is rather problematic that not all dictionary producers characterise their dictionaries explicitly or with the necessary scientific rigour since this is what is supposed to help a potential user choose a specific dictionary according to his profile and intended use of the dictionary. Often, the producers simply mention these categories for the sake of appearance, cf. FuertesOlivera and Tarp (2014: 55).

The following section presents some of the problems that were identified when a comparison was made of the introductions presented here in Section 2.1 to the meaning explanations in the dictionaries. 


\subsection{Problems with the meaning explanations}

The following is a list of the problems identified in the analysis of the investigated dictionaries. Some of these problems have been identified before in lexicographical literature in connection with general dictionaries, e.g. Lombard (1991), but in the present discussion of these points, the criticism will be connected to the user and user situation as well as to sport and fitness, which to this author's knowledge has not been done previously. A selected number of these points - no. 2, 3, 6, 8, 9 and 10 - regarding the incorporation of specialised data in the investigated dictionaries is elaborated below.

1. Inaccuracy: The explanations are incorrect in terms of content; examples from other subject fields can be found in e.g. Bergenholtz and Kaufmann (1996) and Hashimzade et al. (2014)

2. Over-specification: The explanations are too narrow in terms of the specialised field; they focus only on the most popular branches of sport in the country of production

3. Under-specification or Simplification: The explanations are so simplified that you cannot distinguish the relevant lemma from other related lemmata, cf. the purpose of the differentia specifica(e) in a classical definition

4. Irrelevance: The explanations contain non-relevant data, i.e. data that do not support the given dictionary function

5. Circularity: The explanations incorporate the lemma or a derivation, which means that the user will most likely need to make an additional lookup or is left with no help; this is called a derivational definition, cf. Wingate (2002: 35)

6. Unsuitable formulations: The explanations are not explained in a way that serves the intended user in the intended user situation

7. Synonym definitions: The explanations contain only a synonym that functions as a cross-reference to another lemma or other lemmata, which results in unnecessary additional look-ups, or that is assumed to be known by the user; see also Lew (2013: 298)

8. Non-lemmatisation: Non-lemmatisation especially of analytical compounds and especially of terms in running and fitness training

9. Scientific uncertainties: Non-expression of scientific uncertainties or of recent scientific research results

10. Diatechnical markers or Subject labels: Inconsistency in or lack of marking of specialised fields in the meaning explanations, cf. Rull (2003) and Van der Merwe and Fuertes-Olivera (2014) 
11. Dependency: The definitions depend on preceding meaning explanations, i.e. they are not autonomous and cannot be understood independently, cf. Lew (2013: 299)

\section{Point 2: Over-specification}

In Agerbo (2015), the term red card is discussed based on its description in three English and two Danish general online dictionaries. In the current study, this has been expanded to 17 dictionaries (the rest of the analysed dictionaries did not contain this lemma), some of them general dictionaries, others sports (multi-field or single-field) dictionaries. The result from an expanded study of the same term provides the same conclusion as the smaller study:

Almost all the dictionaries that have lemmatised red card associate this term with its use in football, which is problematic because the term has different meanings in different sports. Besides football, Dictionaries 3 and 43 also mention rugby, and Dictionary 4 also mentions handball in which (it is implicitly argued) the red card has the same function as in football. Dictionaries 2, 9 and 21 take a more general approach, either stating that the explanation is in sports or mentioning football as an example of a sport in which the red card is used. Dictionary 28 does not even mention the relevant sport (there is no diatechnical marker and no sport is explicitly mentioned, cf. Point 10) but based on the explanation of the term, it appears that this dictionary also describes the use of the word in football. In Dictionary 33, it is demonstrated that the word carries different meanings in different sports, but even in this dictionary, the treatment is too narrow in terms of the specialised fields since only field hockey, soccer, volleyball and wrestling are mentioned; as explained in Agerbo (2015: 151), the card also has different meanings in for example badminton and race walking. In summary, most of the dictionaries, specialised as well as general, have only selected the use of the word in a single branch of sport, thus neglecting other sports branches. The same is the case for e.g. the lemma heavyweight for which $10(+1)$ of 22 dictionaries only mention boxing, not weightlifting, wrestling or horse shows in which this term is also applied, and these 10 dictionaries are both general and specialised dictionaries: $G=1,3,4,(6), 8,11,41$ and $S=22,25$, 30,33 . Dictionary 6 is in parenthesis because the simple definition only includes boxing, whereas the full definition includes boxing and wrestling.

In a general dictionary, it can be difficult to show all meanings of a sports term as it is applied in the different sports, and general users are most likely not interested in all of them unless they have an information need related to a cognitive situation. In dictionaries for learners of English such as Dictionaries 3, 5 and 8 , the typical approach of selecting the most frequent meanings (the use of the term in the most frequent/popular sports) results in the most useful explanations for both production and reception as these users will most likely come across the word in its most frequent use, i.e. in football. However, in dictionaries for native speakers such as Dictionaries 2 and 9, it would have been 
better (also) to present the user with explanations of the infrequent meanings of the term (e.g. in English culture, this could be in badminton, handball and/or race walking) as most native speakers will most likely be familiar with the frequent uses, whereas coming across the infrequent uses in a text (i.e. in a reception situation) will result in an information need and entail a lookup situation.

Some of the specialised dictionaries partially narrow down the sports fields they cover in the introductions, e.g. Dictionaries 19 and 23, of which the latter states that the area of attention is, "American; popular; on the collegiate or professional level; modern", but none of the investigated dictionaries apart from Dictionary 25 provides a complete list of covered sports (there is a list in Dictionary 18, but it is not complete). This means that the user cannot know whether a sport has been intentionally deselected or has been overlooked. For example, in the Danish general and sports dictionaries, e.g. Dictionary 14, the explanation of handball covers only the use of the word in the Danish invented sport, in which two teams each with seven players try to score goals, whereas in a number of the English general and sports dictionaries, e.g. Dictionary 6, only the American game with the same name, in which two or four players try to hit a ball against a wall, is mentioned.

Table 3: Red card

\begin{tabular}{|c|c|c|}
\hline \multicolumn{3}{|r|}{ Explanations of the lemma red card } \\
\hline 1 & G & $\begin{array}{l}\text { in football, a small, red card that is shown by the referee (= the official who is } \\
\text { responsible for making certain that the rules are followed) to a player who has not } \\
\text { obeyed a rule and who is therefore not allowed to continue playing }\end{array}$ \\
\hline 2 & G & $\begin{array}{l}\text { (sport) a card of a red colour displayed by a referee to indicate that a player has been } \\
\text { sent off }\end{array}$ \\
\hline 3 & G & $\begin{array}{l}\text { In football or rugby, if a player is shown the red card, the referee holds up a red card } \\
\text { to indicate that the player must leave the pitch for breaking the rules. }\end{array}$ \\
\hline 4 & G & $\begin{array}{l}\text { a red card held up by the REFEREE in a football match, to show that a player has done } \\
\text { something against the rules and will not be allowed to play for the rest of the game } \\
{[\leftrightarrow \text { yellow card] }}\end{array}$ \\
\hline 5 & G & $\begin{array}{l}\text { a card shown to a football player for a serious offence against the rules, ordering } \\
\text { them to leave the field. A player is shown a yellow card for a minor offence and if } \\
\text { they are shown another yellow card for a second offence, they are then automatically } \\
\text { shown a red card too. }\end{array}$ \\
\hline 6 & G & $\begin{array}{l}\text { soccer: a red card that a referee holds in the air to indicate that a player who has bro- } \\
\text { ken the rules of the game will not be allowed to continue playing }\end{array}$ \\
\hline 8 & G & $\begin{array}{l}\text { (in football (soccer)) a card shown by the referee to a player who has broken the } \\
\text { rules of the game and is not allowed to play for the rest of the game }\end{array}$ \\
\hline 9 & G & $\begin{array}{l}\text { (In soccer and some other games) a red card shown by the referee to a player who is } \\
\text { being sent off the field }\end{array}$ \\
\hline 14 & G & $\begin{array}{l}\text { (translation) card which a football or handball referee present when he dismisses a } \\
\text { player }\end{array}$ \\
\hline
\end{tabular}




\begin{tabular}{|c|c|c|}
\hline 21 & $S$ & $\begin{array}{l}\text { A red card shown by the referee (as in international soccer) to indicate that a player } \\
\text { is being sent off. }\end{array}$ \\
\hline 22 & S & $\begin{array}{l}\text { Soccer: The red card, about the size of an ordinary playing card that is shown by the } \\
\text { referee to indicate a player is being sent off the field for a violation of the rules. }\end{array}$ \\
\hline 23 & S & $\begin{array}{l}\text { ASSOCIATION FOOTBALL This is shown by a referee to indicate that a player is } \\
\text { being sent off }\end{array}$ \\
\hline 28 & S & $\begin{array}{l}\text { A playing card-sized card that a referee holds up to signal a player's removal from } \\
\text { the game; the player's team must play the rest of the game shorthanded; presented } \\
\text { for violent behavior or multiple rule infractions (two yellow cards = one red card) }\end{array}$ \\
\hline 30 & $\mathrm{~S}$ & $\begin{array}{l}\text { (association football) a red-colored card shown by the referee to a player who is } \\
\text { being sent off, either because he has committed a serious foul or because he has } \\
\text { already been shown two yellow cards }\end{array}$ \\
\hline 33 & $\mathrm{~S}$ & $\begin{array}{l}\text { - Red card (Field Hockey) } \\
\text { - Red card (Soccer) } \\
\text { - Red card (Volleyball) } \\
\text { Field hockey ... } \\
\text { Soccer: A player is dismissed from the field of play if the referee shows him a red } \\
\text { card. This happens either because the player has received two yellow cards in the } \\
\text { same match, or because the referee judges that he has committed a single offense that } \\
\text { warrants a sending off in its own right. When a player has been sent off, his team } \\
\text { must play the rest of the game with } 10 \text { players (unless further players are dismissed). } \\
\text { Volleyball ... } \\
\text { Wrestling ... }\end{array}$ \\
\hline 41 & $\mathrm{G}$ & $\begin{array}{l}\text { soccer a red card that a referee holds in the air to indicate that a player who has bro- } \\
\text { ken the rules of the game will not be allowed to continue playing - compare YELLOW } \\
\text { CARD }\end{array}$ \\
\hline 43 & $\mathrm{~S}$ & $\begin{array}{l}\text { (Under the label soccer): Expulsion (red card): Players are expelled if they commit a } \\
\text { serious foul, are violent, use abusive, offensive, or insulting language, or receive a } \\
\text { second yellow card during the game. } \\
\text { (Under the label rugby): A red card is handed out in the case of especially rough play } \\
\text { or dangerous behaviour, or if a player has repeatedly contravened the rules. It results } \\
\text { in the player's immediate expulsion. }\end{array}$ \\
\hline
\end{tabular}

\section{Point 3: Under-specification or Simplification}

For the lemma goalkeeper (focussing on the association football meaning), many of the explanations are so simplified that you cannot distinguish the relevant lemma from other related lemmata, i.e. this is a case of under-specification. The analysed explanations can be divided into the following three groups (though Dictionary 43 is an exception as its explanation involves the following components: the goalkeeper is the last line of defense + he stops shots + he has certain privileges + he directs the defense): 
1. A person whose job it is to guard the goal, defend the goal, protect the goal, or prevent the ball from going into the goal $(3,4,5,6,7,8,9,10,11$, $22,30,41,42$ )

2. + a player (who stands) in the goal or a player who stands in front of the goal $(1,2,13,14,15)$

3. + a player who has certain privileges $((12), 18,19,21,28,33)$

It is remarkable that none of the general dictionaries include data on the special privileges, which is actually the main characteristic that distinguishes this player from the other (defending) players. It is the task of all defending players to stand somewhere in front of the goal, guard the goal and try to prevent the opponents from scoring, not only the goalkeeper's job, and for example in case of a corner kick, some of the defending players also stand in the goal next to the goalposts to help the goalkeeper, which means that both groups 1 and 2 above are not particularly good at describing the meaning of goalkeeper for neither communicative nor cognition purposes. In addition to these criteria, a goalkeeper must always wear clothing that is different from the other team players' clothes, making it possible to distinguish this player from all the other players, but this criterion is only mentioned in Dictionary 18.

Of the analysed dictionaries, it is only some of the specialised dictionaries whose explanations can be used for reception for general users, not any of the explanations in the general dictionaries. If a meaning explanation should be incorporated in a general dictionary for reception, it would have to include at least the three points mentioned above though this would still result in a rather broad explanation. Another solution would be to add specifications about the goalkeeper in each sport and make them accessible via links, resembling the approach in Dictionary 33. If the meaning explanation were to be incorporated in a production dictionary, it would not be necessary to distinguish between different sports, and only a rather short explanation would be needed, e.g. "the player who is assigned certain privileges to protect the goal," because the user is interested in data types that can assist him in text production; in this situation, the user (typically) already knows the meaning of the word. For cognition, the explanations provided in Dictionaries 12, 18 and 21 are useful, and this also corresponds somewhat to the description of their function(s) in their introductions, e.g. to add to the sum of knowledge for a sports addict.

Table 4: Goalkeeper

\begin{tabular}{|c|c|c|}
\hline \multicolumn{3}{|r|}{ Explanations of the lemma goalkeeper } \\
\hline 1 & G & (in some sports) the player who stands in the team's goal to try to stop the other team from scoring \\
\hline 2 & G & (sport) a player in the goal whose duty is to prevent the ball, puck, etc, from entering or crossing it \\
\hline 3 & G & A goalkeeper is the player in a sports team whose job is to guard the goal. \\
\hline 4 & G & $\begin{array}{l}\text { the player in a sports team whose job is to try to stop the ball going into the goal [= goaltender } \\
\text { American English] }\end{array}$ \\
\hline
\end{tabular}




\begin{tabular}{|c|c|c|}
\hline 5 & G & the player whose job is to stop the ball going into the goal in games such as football \\
\hline 6 & G & a player who defends the goal in various games (especially soccer) \\
\hline 7 & G & a player who defends the goal in various games (as hockey, lacrosse, soccer) \\
\hline 8 & G & $\begin{array}{l}\text { (in football (soccer), hockey, etc.) a player whose job is to stop the ball from going into his or her } \\
\text { own team's goal }\end{array}$ \\
\hline 9 & G & A player in soccer or field hockey whose special role is to stop the ball from entering the goal. \\
\hline 10 & G & A player assigned to protect the goal in various sports. \\
\hline 11 & G & $\begin{array}{l}\text { In games such as football and hockey, the goalkeeper is the player who guards his or her own } \\
\text { team's goal. }\end{array}$ \\
\hline 12 & $\mathrm{~S}$ & $\begin{array}{l}\text { (translation) player who guards } \rightarrow \text { the goal. } \\
\text { (Bandy) ... } \\
\text { (Football) As the last person in the defense, he has the most responsible role as a mistake made by } \\
\text { him cannot be amended. He has a special role } 1 \text { ) because in his own penalty area he may use his } \\
\text { hands and 2) because none is allowed to push him in this area unless he is holding the ball (i.e. not } \\
\text { fisting it) or intentionally tries to hold back the opponent. When the keeper is holding the ball } \\
\text { none may try to kick it away from him. Requirements to a good goalkeeper are esp. 1) the ability } \\
\text { to read the game, 2) quick reflexes, } 3 \text { ) good with his hands, } 4 \text { ) reliability in the game. To be a very } \\
\text { good goalkeeper, he must also be able to leave the goal at the right moments. A keeper must } 1 \text { ) use } \\
\text { his hands instead of his legs when possible, 2) always try to catch the ball and only fist it when } \\
\text { there is a risk of being pushed to the ground, } 3 \text { ) quickly get the ball away from his field - prefer- } \\
\text { able to one of the wings, } 4 \text { ) at corner kicks position himself at the furthermost goal post, } 5 \text { ) at shots } \\
\text { from the wing position himself at the nearest goal post. The keeper is only permitted to leave the } \\
\text { goal when he is sure that he will catch the ball first; he must do it when an opponent has been able } \\
\text { to dribble away from the last defender in the field. The keeper must cooperate with his backs and } \\
\text { direct them - and other players - when necessary. Of the usual technical skills required by a } \\
\text { field player, the keeper must be good at kicking, especially to a "dead" ball so he can kick his own } \\
\text { goal kicks. The keeper must be good at catching and throwing as well as fisting. } \\
\text { (Handball) ... } \\
\text { (Hockey) ... } \\
\text { (Ice hockey) ... } \\
\text { (Water polo) ... }\end{array}$ \\
\hline 13 & G & (translation) the player in football and similar games who is placed in the goal (in order to defend it) \\
\hline 14 & G & $\begin{array}{l}\text { (translation) player in a ball game who is placed in the goal and whose job it is to prevent the } \\
\text { opponents from scoring, e.g. by catching the ball }\end{array}$ \\
\hline 15 & G & $\begin{array}{l}\text { (translation) a player in e.g. a football or ice hockey team who stands in front of the goal to pre- } \\
\text { vent a score }\end{array}$ \\
\hline 18 & $\mathrm{~S}$ & $\begin{array}{l}\text { A player who guards the goal in certain goal games, notably field hockey, ice hockey, lacrosse, } \\
\text { soccer and water polo. The goalkeeper usually keeps closely within the goal area and virtually } \\
\text { never takes part in offensive maneuvers. He is, as a rule, accorded privileges denied his team- } \\
\text { mates. Abbreviation: G. Other specifications: } \\
\text { Field hockey: ... } \\
\text { Ice hockey: ... } \\
\text { Lacrosse: ... } \\
\text { Soccer: Similar duties to those listed. The goalkeeper, unlike other players, can touch and throw } \\
\text { the ball when he is within the penalty area. He can likewise carry it, but cannot take more than } 4 \\
\text { steps without bouncing it. He has no special privilege when he is outside the penalty area (which } \\
\text { see). His equipment is no heavier than that of other players (he wears no shinguards), but he } \\
\text { should wear colors distinguishing him from other players. He may go anywhere in the field, but } \\
\text { only the player designated by a team to the referee as its goalkeeper may enjoy the special goal- } \\
\text { keeper's privileges listed above. } \\
\text { Water polo: ... }\end{array}$ \\
\hline 19 & $\mathrm{~S}$ & $\begin{array}{l}\text { (field hockey) ... } \\
\text { (ice hockey) ... } \\
\text { (soccer) the player who stands between the posts and is allowed the use of his hands within his } \\
\text { own penalty area. }\end{array}$ \\
\hline
\end{tabular}




\begin{tabular}{|c|c|c|}
\hline 21 & S & $\begin{array}{l}\text { 1. The defensive player in various goal games who normally plays in front of the goal he is } \\
\text { defending to keep the ball or puck from going in for a score. The goalkeeper is the team's last line } \\
\text { of defense and he often is allowed to use special equipment and is accorded certain privileges } \\
\text { while in his normal position that are denied his teammates. The goalkeeper in soccer is the only } \\
\text { player who is permitted to play the ball with his hands but only while he is within the penalty } \\
\text { area... }\end{array}$ \\
\hline 22 & S & The player assigned to protect the goal. \\
\hline 28 & S & $\begin{array}{l}\text { The player positioned directly in front of the goal who tries to prevent shots from getting into the } \\
\text { net behind him; the only player allowed to use his hands and arms, though only within the pen- } \\
\text { alty area. }\end{array}$ \\
\hline 30 & S & (general ) the player who defends the goal in a game such as association football \\
\hline 32 & S & $\begin{array}{l}\text { Field hockey ... } \\
\text { Ice hockey: ... }\end{array}$ \\
\hline 33 & S & $\begin{array}{l}\text { Each team has a designated goalkeeper, whose role is to stop the opposing team from scoring a } \\
\text { goal. The goalkeeper is the only player who is allowed to handle the ball, but this is permissible } \\
\text { only inside his own penalty area. }\end{array}$ \\
\hline 41 & G & a player who defends the goal in various games (especially soccer) - compare GOALTENDER \\
\hline 42 & G & the soccer or hockey player assigned to protect the goal \\
\hline 43 & S & $\begin{array}{l}\text { The only player allowed to use his hands, he must stop shots from the opposing team. He is his } \\
\text { team's last line of defense and directs his teammates when the other team is attacking. }\end{array}$ \\
\hline
\end{tabular}

\section{Point 6: Unsuitable formulations}

Usually, explanations are targeted towards a specific intended user type. This was clearly the case in the learner's dictionaries in which many applied a restricted vocabulary and simple syntax (for a criticism of restricted vocabularies, see De Schryver and Prinsloo (2011: 8)). However, not all the investigated dictionaries managed to match the language to the intended user.

Many anatomical and physiological terms that once were foreign to the general dictionary user have today become part of the general vocabulary due to the increased popularity of fitness and sport, a process known as de-terminologisation, see e.g. Meyer and Mackintosh (2000). This is for example happening with words such as ATP, cardiovascular, deltoid muscle (or deltoids), hypertrophy and plyometrics. Such words should therefore be incorporated into both general and specialised dictionaries. Even though these may be seen as specialised words (at least at the initial incorporation in general dictionaries), the meaning explanations of these should be formulated in a way that the intended user easily understands them. An example of this is presented by Bergenholtz and Kaufmann (1997: 115-117), who suggest different explanations of gene for laymen and semi-experts, respectively. In Dictionary 24 , a specialised dictionary, the very first lemma in the central list, abdomen, is explained as "[t]he part of the body in mammals that lies between the thorax and the pelvis and encloses the viscera, or internal organs of the body (commonly called the intestines); the belly." According to the dictionary book jacket, the dictionary "uses concise explanations to make the world of exercise understandable to everyone." In terms of vocabulary, the first part of the explanation is not suitable for 
everyone ("everyone" is also rather a bold statement to make). Dictionary 9, a general dictionary, presumably targeted at general users who are native speakers of English, presents the same problem, "[t]he part of the body of a vertebrate containing the digestive and reproductive organs; the belly" (belly, however, is explained as "[t]he front part of the human trunk below the ribs, containing the stomach and bowels", which is better suited for the English speaking general user). Dictionary 1 , also a general dictionary, manages much better to formulate its content to its target user (advanced learner), "the lower part of a person's or animal's body, containing the stomach, bowels, and other organs, or the end of an insect's body" though it could be discussed whether this is one or actually two explanations.

If we also compare Dictionaries 1 and 9 in their explanations of ATP, the explanation in Dictionary 9 is better suited for a semi-expert than for the intended non-expert, "[a] compound consisting of an adenosine molecule bonded to three phosphate groups, present in all living tissue. The breakage of one phosphate linkage (to form adenosine diphosphate, ADP) provides energy for physiological processes such as muscular contraction" whereas the explanation in Dictionary 1 (for advanced learners) is directed at a learner or even a general user, "an important chemical in the cells of living organisms that store energy and releases it when it is needed."

\section{Point 8: Non-lemmatisation}

Some of the specialised dictionaries contained a number of lemmatised compounds, e.g. Dictionary 18 contained 45 lemmata with the word running, e.g. running broad jump and running half gainer, many of them used in fancy diving. However, many of the sports dictionaries did not include such compounds (at least not in the case of the test compounds) and neither did most of the general dictionaries. This is not a surprise as the general practice is not to lemmatise analytical lemmata, i.e. lemmata whose meanings can be inferred (or are assumed to be inferable) based on the single words constituting the compound. However, for reception, explanations of compounds such as barefoot running and protein drink, which may seem easily interpretable, should be provided, and neither for laymen nor semi-experts should the explanations simply be: 'running barefooted' or 'running without footwear' and 'a drink containing proteins', cf. Bergenholtz and Agerbo (2014a), who suggest the following explanation of protein drink for reception in a general dictionary:

drink that consists of protein rich ingredients or protein powder mixed with water or milk; typically used by sportsmen to maximize the effect of a workout, by patients who have gone through a surgery, or people on a diet in which case they need to increase their consummation of proteins and decrease their consummation of sugar

The simple explanations mentioned above may be useful in a production dictionary, but they do not help any of the users when they have an information 
need related to reception - a more detailed explanation is needed, cf. an analysis of corpus data, which for the lemma protein drink showed that people often discuss (1) when this drink is used and (2) for what purpose. In a sports dictionary, only the comment about sportsmen in the explanation above is relevant, and the rest after the semi-colon should therefore be excluded from the explanation. In a reception or cognitive sports dictionary for semi-experts, the explanation might also contain data on how the protein drink affects the body physiologically, but this is not relevant in a layman explanation. Thus, the amount of detail provided will depend on both the user and user situation.

None of the analysed dictionaries have lemmatised the compound barefoot running, but neither in this case can the user actually infer its meaning in a reception situation, e.g. that barefoot running could also be done in minimal shoes and that they are designed for the foot to land on the surface in a specific way. A suggestion for a general dictionary could be:

special way of running that involves running barefooted or in minimal shoes, which have a very thin sole, making it possible to run as naturally as possible, i.e. as if you were not wearing shoes, and which results in you landing on flat feet with your weight on the anterior part of your feet

Not only (analytical) compounds were often disregarded, but also terms in running and fitness. Though the present study was not a statistical study, it was somewhat surprising to find that a number of the general dictionaries, for which their producers claim that they are regularly updated, did not contain such terms even though running and fitness is today very popular, which is why they should be included in modern dictionaries.

\section{Point 9: Scientific uncertainties are not expressed}

The word sidestik (Eng. side stitch - not lemmatised in the English dictionaries, cf. Point 8), appeared in Dictionary 13, a Danish general dictionary, in which the explanation is (translation), "pricking pain in the right side of the body, e.g. due to excessive strain." As for the first part: side stitches often occur on the right side, but they can also occur on the left, i.e. it is incorrect only to write that it is the right side in which it occurs (cf. Point 1 in the list). As for the second part: no scientific research has yet been able to identify the causes of side stitches; there are many theories and suggestions as to why side stitches occur and how to prevent them from occurring, but so far no scientific evidence has been able to establish any of this as a fact. This means that pointing at "excessive strain" in the explanation is a scientific uncertainty, not a fact, which the user is not made aware of. In Dictionary 27, a specialised dictionary on food and exercise, the author sometimes comments on scientific uncertainties, e.g. for the lemma muscle growth, it is explained that this is mainly due to an increase in the muscle fibres, but that "a growing body of evidence" suggests 
that it could also be due to an increase in the number of fibres, though this has not been demonstrated conclusively. The same is expressed in Dictionary 44 for the lemma hypertrophy in which it says that hypertrophy "may also be due to an increase in the number of muscle fibres" ("may" expresses uncertainty). Such uncertainties are not only needed in specialised dictionaries, but should also be expressed in some general dictionaries that include such terms. Dictionary 9, a general dictionary, states that hypertrophy is "[t]he enlargement of an organ or tissue from the increase in size of its cells", i.e. this dictionary only states verified facts and ignores the scientific uncertainty, which is also problematic. As mentioned by Leroyer (forthcoming), explanations should be updated whenever progress in science and technology modifies meaning and may jeopardise understanding. For a word such as stretching, it should be made clear that there is no agreement as to how much it helps or how much stretching one should do, and for a term such as compression sock (one of the test words that was not lemmatised in any of the analysed dictionaries), the uncertainties concerning its function should also be highlighted, at least for cognition, but possibly also for reception if this explanation comments on the function of this type of sock as in the following suggested meaning explanation:

sock made of cotton, polyamide and spandex that covers the lower part of the leg and increases the pressure on the peroneus during physical activity, e.g. running or bicycling, which improves the blood circulation and thus entails better performance, improved endurance and decreased recovery time; in recent years, compression socks have become very popular in sports, but scientific research has yet not been able to verify the performance-enhancing effect of these socks when using them for physical activities

Admittedly, whether such comments on scientific research is useful for all users in a reception situation could be questioned, as a user looking up the term after having read it in a text might not be interested in these data. But, simply stating the assumed causes, functions etc. of the item as a fact is not helping the user either. For a general user in a production situation, such comments should not be provided. An interested layman and a semi-expert would want to be provided with these data both for reception and cognition. Gouws and Tarp (forthcoming) explain that information overload must be avoided, and therefore the lexicographer will have to pay attention to the intended user and user situation when making decisions about what to include and exclude from the meaning explanation. It is not a question of whether the meaning components are semantic or encyclopaedic, and there is not one correct solution, but many possible ones of which the lexicographer must choose the most useful one for the given function, cf. Nielsen (2010).

\section{Point 10: Diatechnical markers or Subject labels}

In Dictionary 28, a sports dictionary, no diatechnical markers were used at all, which means that for lemmata used in several sports branches, the user is left 
with no help to determine the context, thus its usefulness is limited even though the user knows that the general field is sport. In a number of the other specialised dictionaries, e.g. Dictionary 21, each meaning of a term is marked with a diatechnical marker, e.g. field hockey and soccer; in some cases, a general explanation is provided before the more specific explanations, thus helping laymen, who are not interested in reading about the meanings in all the different sports. In many of the general dictionaries, the use of diatechnical markers is unsystematic, e.g. in Dictionary 14, a Danish general dictionary (see Rull (2003) for a similar analysis of the application of diatechnical markers in Spanish general dictionaries). On its website, the producers write that (a) a meaning is marked with a field marker if the most typical use of this word is in this specific field and if it is less known in general language, and that (b) if the word is monosemous and used in a specialised field, this is not marked, but its relation to the field will be mentioned directly or indirectly in the explanation. As can be seen in Table 5, this approach has resulted in highly different solutions to the presentation of data in the case of the sports field; only the diatechnical marker SPORT is applied, thus all subfields and specific sports, e.g. ball games and tennis, will have to be mentioned using other strategies, which the dictionary user might have difficulties understanding correctly. For example, what does "and similar sports" involve (no. 3), why is "in ball games" written before the explanation for skytte, but inside the explanation for tackling (no. 7), and is the comment at the end of the explanation of back a separate explanation (no. 17)? As argued by Van der Merwe and Fuertes-Olivera (2014: 84) in their analysis of South African wine dictionaries, subject labels are very useful, both for communication-oriented functions (though especially in bilingual dictionaries) and also in cognitive-oriented dictionaries. However, they have to be applied in a way that helps the user understand the data he is reading instead of confusing him.

Table 5: Diatechnical markers in Dictionary 14 (Den Danske Ordbog)

\begin{tabular}{|c|l|l|l|}
\hline Type & $\begin{array}{l}\text { Marking of the field(s) in } \\
\text { or around the explanation }\end{array}$ & \multicolumn{1}{|c|}{$\begin{array}{c}\text { Examples } \\
\text { (translations) }\end{array}$} & $\begin{array}{c}\text { Terms* } \\
\text { (translations) }\end{array}$ \\
\hline 1 & $\begin{array}{l}\text { All the relevant sports } \\
\text { branches are indirectly } \\
\text { integrated in the explana- } \\
\text { tion }\end{array}$ & $\begin{array}{l}\text { card shown by football or handball } \\
\text { referee when he sends off a player }\end{array}$ & $\begin{array}{l}\text { red card, line player, } \\
\text { hook, jab, ring corner, } \\
\text { uppercut, marathon } \\
\text { run }\end{array}$ \\
\hline 2 & $\begin{array}{l}\text { The general field, sport, is } \\
\text { indirectly integrated in the } \\
\text { explanation }\end{array}$ & the fixed time that a sports game lasts & $\begin{array}{l}\text { game time (pol1), box- } \\
\text { ing, ironman(pol2a), } \\
\text { weightlifting, top } \\
\text { seeded }\end{array}$ \\
\hline 3 & $\begin{array}{l}\text { Examples of the relevant } \\
\text { sports branches are men- } \\
\text { tioned in the explanation }\end{array}$ & $\begin{array}{l}\text { a way of playing in e.g. ice hockey and } \\
\text { football in which a player uses a board or } \\
\text { a co-player to quickly send the puck or } \\
\text { ball past an opponent }\end{array}$ & $\begin{array}{l}\text { (do a) one-two, interval } \\
\text { training }\end{array}$ \\
\cline { 3 - 4 } & $\begin{array}{l}\text { medium heavy weight class in boxing } \\
\text { and similar sports - e.g. in amateur } \\
\text { boxing 71-75 kg }\end{array}$ & middleweight \\
\hline
\end{tabular}




\begin{tabular}{|c|c|c|c|}
\hline 4 & $\begin{array}{l}\text { The relevant sports } \\
\text { branches are mentioned in } \\
\text { the explanation }\end{array}$ & $\begin{array}{l}\text { person who manages fights in boxing, } \\
\text { wrestling and martial arts and who } \\
\text { makes sure that the rules are followed }\end{array}$ & $\begin{array}{l}\text { referee, knockout, dou- } \\
\text { ble fault, tennis player, } \\
\text { match ball }\end{array}$ \\
\hline 5 & $\begin{array}{l}\text { The relevant sport is men- } \\
\text { tioned before the explana- } \\
\text { tion }\end{array}$ & $\begin{array}{l}\text { in football: a kick to the ball taken from } \\
\text { one of the four corners, and which is } \\
\text { awarded to the attacking team when the } \\
\text { ball crosses the back line after last being } \\
\text { touched by a player from the defending } \\
\text { team }\end{array}$ & corner kick \\
\hline 6 & $\begin{array}{l}\text { A subfield is mentioned } \\
\text { before the explanation }\end{array}$ & $\begin{array}{l}\text { in ball games: player who participates in } \\
\text { the attack in one side of the field }\end{array}$ & wing \\
\hline \multirow[t]{2}{*}{7} & \multirow{2}{*}{$\begin{array}{l}\text { A diatechnical marker is } \\
\text { mentioned before the } \\
\text { explanation }+ \\
\text { A subfield is mentioned }\end{array}$} & $\begin{array}{l}\text { SPORT in ball games: player who (with } \\
\text { luck) kicks or throws the ball towards or } \\
\text { in goal }\end{array}$ & shooter \\
\hline & & $\begin{array}{l}\text { SPORT tackling an opponent in ball } \\
\text { games }\end{array}$ & tackle \\
\hline 8 & $\begin{array}{l}\text { A diatechnical marker is } \\
\text { mentioned before the } \\
\text { explanation }\end{array}$ & $\begin{array}{l}\text { SPORT area close to one of the sides of } \\
\text { the football field where coaches, audience } \\
\text { and others are placed }\end{array}$ & $\begin{array}{l}\text { side line (pol1a), wing } \\
\text { (pol1c), midfield (pol2), } \\
\text { line }(p o l 2 b), \text { line } \\
(p o l 2 c), \text { ace }\end{array}$ \\
\hline 9 & $\begin{array}{l}\text { A diatechnical marker is } \\
\text { mentioned before the } \\
\text { explanation + } \\
\text { An additional narrowing, } \\
\text { the typical sport, is men- } \\
\text { tioned after the explanation }\end{array}$ & $\begin{array}{l}\text { SPORT area between the goalmouths in a } \\
\text { field where the midfielders primarily } \\
\text { work, and from where the attack is initi- } \\
\text { ated - particularly in football }\end{array}$ & midfield (pol1) \\
\hline 10 & $\begin{array}{l}\text { Examples of relevant } \\
\text { sports are mentioned after } \\
\text { the explanation }\end{array}$ & $\begin{array}{l}\text { special kind of throw thrown directly } \\
\text { towards the goal which a team is awarded } \\
\text { after a foul has been made by the oppo- } \\
\text { nents - occurs e.g. in handball and bas- } \\
\text { ketball }\end{array}$ & penalty throw \\
\hline 11 & $\begin{array}{l}\text { A diatechnical marker is } \\
\text { mentioned before the } \\
\text { explanation + } \\
\text { Indirect examples of sports } \\
\text { branches are integrated in } \\
\text { the explanation at the end }\end{array}$ & $\begin{array}{l}\text { SPORT line that marks the long side on } \\
\text { e.g. a football field or tennis court }\end{array}$ & side line (pol1) \\
\hline 12 & $\begin{array}{l}\text { A general diatechnical } \\
\text { marker is mentioned } \\
\text { before the explanation }+ \\
\text { Examples of relevant } \\
\text { sports branches are inte- } \\
\text { grated in the explanation at } \\
\text { the end }\end{array}$ & $\begin{array}{l}\text { SPORT shooting or hitting a ball hard } \\
\text { before it touches the ground in e.g. foot- } \\
\text { ball or tennis }\end{array}$ & volley \\
\hline 13 & $\begin{array}{l}\text { A diatechnical marker is } \\
\text { mentioned before the } \\
\text { explanation + } \\
\text { The specific sport is men- } \\
\text { tioned indirectly in the } \\
\text { explanation }\end{array}$ & $\begin{array}{l}\text { SPORT each of the three or more rounds } \\
\text { lasting three or two minutes that a boxing } \\
\text { match is divided into }\end{array}$ & round \\
\hline 14 & $\begin{array}{l}\text { A general diatechnical } \\
\text { marker is mentioned } \\
\text { before the explanation }+ \\
\text { The specific sport is men- } \\
\text { tioned in the explanation }\end{array}$ & $\begin{array}{l}\text { SPORT part of a set in tennis where only } \\
\text { one of the players has the right to serve } \cdot \text { is } \\
\text { won by winning at least four duels; a } \\
\text { player must win minimum six games } \\
\text { before he has won the set }\end{array}$ & game (pol4a) \\
\hline 15 & $\begin{array}{l}\text { A diatechnical marker is } \\
\text { mentioned before the } \\
\text { explanation }+ \\
\text { The relevant sports } \\
\text { branches are mentioned } \\
\text { after the explanation }\end{array}$ & $\begin{array}{l}\text { SPORT bar with a number of weight } \\
\text { plates secured to it - used in weight } \\
\text { lifting and weight training }\end{array}$ & barbell \\
\hline
\end{tabular}




\begin{tabular}{|c|l|l|l|}
\hline $16 a$ & $\begin{array}{l}\text { Integrated in the explana- } \\
\text { tion at the end are some } \\
\text { examples of relevant sports } \\
\text { branches }\end{array}$ & $\begin{array}{l}\text { passing the ball across the field in e.g. } \\
\text { football }\end{array}$ & $\begin{array}{l}\text { diagonal pass, clay court, } \\
\text { serve (pol1) }\end{array}$ \\
\hline 17 & $\begin{array}{l}\text { At the end are some exam- } \\
\text { ples of relevant sports } \\
\text { branches and these are } \\
\text { used to comment further } \\
\text { on the core explanation }\end{array}$ & $\begin{array}{l}\text { player in certain ball games who primarily } \\
\text { has defensive tasks in one side of the field } \\
\text { - also has an important offensive role in } \\
\text { e.g. handball }\end{array}$ & back \\
\hline 18 & $\begin{array}{l}\text { An additional narrowing } \\
\text { in the form of the most } \\
\text { typical sport is mentioned } \\
\text { after the explanation }\end{array}$ & $\begin{array}{l}\text { ball that is played or jumps back into play } \\
\text { after a pass, a shoot or a duel - especially } \\
\text { in football }\end{array}$ & second ball \\
\hline 19 & $\begin{array}{l}\text { No marking of the general } \\
\text { field nor of more specific } \\
\text { sports branches }\end{array}$ & $\begin{array}{l}\text { the time a player spends on the field } \\
\text { during a game }\end{array}$ & $\begin{array}{l}\text { game time (polla), list of } \\
\text { top scorers, running } \\
\text { shoe, forehand, serve } \\
\text { (polla), ultra-running }\end{array}$ \\
\hline
\end{tabular}

2.3 Main guidelines for writing meaning explanations of specialised terms

(1) The data must be lexicographically relevant Lombard: completeness

(2) The explanation must be easily understandable for the intended user type Lombard: clarity

(3) The data must be correct and reliable Lombard: accuracy

(4) The meaning explanation must be independent Lombard: independency

(5) The incorporation of polysemes should be based on the user and user situation, not frequency

(6) Scientific uncertainties should be presented in explanations as uncertainties, not as fact, and they should be mentioned whenever they are relevant for the given function

(7) The relevant sports field(s) should be marked with field labels in a way that supports the dictionary function and that makes it possible to quickly and easily access the relevant explanation

Lombard (1991) comments on some of the same points for writing good meaning explanations, though not all are similar and not all the conclusions are the same. The first guideline, relevance, means that the incorporated semantic elements must be selected based on their relevance according to the function. 
Nothing more (over-specification) and nothing less (under-specification) than what is relevant for the intended user situation and user should be incorporated. Lombard agrees with this, but he considers encyclopaedic or extra-linguistic information non-essential whereas relevance is not based on a distinction between semantic and encyclopaedic data. The second guideline, clarity, is also mentioned by Lombard, but in the current paper it is considered from a functional perspective, i.e. that the amount of detail in the explanation, the sentence structure, etc. should depend on the user, which means that the explanation should not always be simple and without detail. The third guideline is not worth discussing as this is something all lexicographers would agree with. However, it should be emphasised that correct and reliable is not the same as "the truth". The lexicographer does not present the truth, but produces a tool that among other things contains explanations that are incorporated in order to help a specific user type with a specific type of need in a specific type of user situation. The fourth guideline is something that can be dealt with in an e-tool by turning some of the words in the explanations into links so the user can easily be taken to the relevant article or by presenting additional explanations as pop-up text when the mouse is moved over the relevant word. But lexicographers should avoid both article internal and article external dependence as this will always mean extra work in the look-up situation for the dictionary user. The fifth guideline entails that the selection of polysemes in a dictionary should not only be based on the most frequent meanings of a term, but what explanations different users may be assumed to be looking for in different situations. The sixth guideline is particularly relevant for specialised terms. In Dictionary 13, a term such as sort hul (Eng. black hole) is explained and the dictionary mentions that this phenomenon is believed to exist, but that this has yet not been proven. The same approach should be applied for sports terms such as compression sock, side stitch and barefoot running. The seventh guideline means that whenever it is possible and useful to describe the specialised field (especially in a general dictionary), this should be done with a diatechnical marker. The number of markers could be expanded to include all the sports selected for the given dictionary instead of the general marker SPORT. Also, the marker FITNESS should be added to modern dictionaries.

A couple of extra guidelines could be added to the above list: (8) the empirical basis used for the production of explanations should be selected according to the dictionary function and the type of lemma being described, and (9) the semantic elements must be placed in an order that supports the dictionary function. The eighth guideline is not discussed above in Section 2.2, but is derived from descriptions of the empirical basis in the introductions of the different dictionaries. Most general language dictionaries are today corpusbased, but when it comes to explanations of specialised terms, other sources such as experts and other written texts are more useful for deriving semantic components for the explanations, cf. Bergenholtz and Agerbo (2014b). A corpus-based approach, e.g. applied in Dictionaries 4, 5, 9 and 13, will not always 
provide sufficient data for explanations of specialised terms as the corpora are not compiled with specialised texts, cf. Bergenholtz and Kaufmann (1996). This guideline concerning the empirical basis is indirectly connected to the meaning explanation. The ninth and final guideline is not discussed above either but was derived when looking at the explanations presented in the next section, which are connected to interpretative and operative functions: for some lemmata, the selection and order of presentation of semantic components will differ across functions, e.g. the explanations of press-up. It is not for all lemmata that a difference will occur in the order of the components, and some components that are considered more essential than others will always occur initially.

These guidelines highlight that more attention should be given to sports terms especially in general information tools, and also in specialised tools. These dictionaries are useful for some users in some situations, but no clear lexicographical theory appears to have been applied in the production of these dictionaries. The general dictionaries are mainly driven by a linguistic approach, and many of the specialised dictionaries are written by for example sports journalists with no knowledge about lexicographical theory.

\subsection{Additional findings}

A couple of intriguing discoveries were made in the analyses of Dictionaries 12, 18, 21, 25, 27, 36 and 44: Danish Sports Lexicon (1944/1945), The Dictionary of Sports (1949), Webster's Sports Dictionary (1976), What's What in Sports - the Visual Glossary of the Sports World (1984), Food and Fitness: Dictionary of Diet and Exercise (1997/2003), The Visual Dictionary of Baseball (2001) and The Encyclopedia of Exercise, Sport and Health (2004). These demonstrated the incorporation of explanations that do not aim to satisfy a user's need in communicative and cognitive situations, but which are incorporated into dictionaries with explicit or implicit operative and/or interpretative functions, which are functions that have only been mentioned in a small number of articles in the lexicographic literature, e.g. Tarp (2008b), Tarp (2008c), Bergenholtz, Bothma and Gouws (2015) and Agerbo (2015), but which have yet not been fully integrated into lexicographical theory.

\subsubsection{The operative function}

In Dictionaries 12, 18, 27 and 36, the meaning explanations do not only comment on the actual meanings of the lemmata, but they also instruct the user in carrying out the exercise, movement or something else to which the lemma refers. For example, in Dictionary 12, the lemma Hovedspil (Eng. heading) involves an explanation of the part(s) of the head with which you can hit the ball; a description of how you should approach the ball; it explains that you 
should keep your eyes on the ball until you hit it; that you should head the ball when defending and attacking; and that you should head the ball downwards when trying to score a goal. In Dictionary 18, the description of crawl is much more instructive than what you typically find in dictionaries. In this case, the way of breathing, turning of the head, movement of the arms and movement of the legs is much more detailed than if the word were to be described for reception. Actually, in its introduction, Dictionary 12 states that it, among other things, aims to be an instructive reference work, i.e. it not only wants to explain to a user what something is, but also how to do it. Dictionary 18 , however, does not mention instructions as part of its function. In Dictionary 27, the introduction states that "the book provides the information you need to make sensible decisions about the food you eat and the activities you undertake." It does not explicitly mention instructions for these activities, but if we look at e.g. the lemma press-up, this article does not only contain an explanation, it also provides a separate exercise instruction, both presented as a written and a visual explanation. Dictionary 36 does not contain an introduction.

Figure 1: Press-up in Dictionary 27

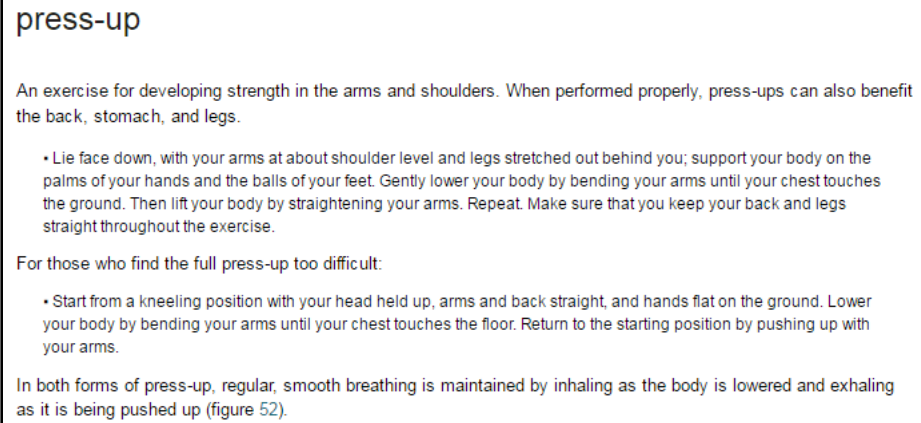

What has been identified here is an operative function (i.e. instructive), which only one of the three dictionaries explicitly mentions in the introduction as one of its functions. A dictionary with an operative function is designed to help a user who has an information need that needs to be solved so he can carry out a mental or physical act. This function is one that we are familiar with from handbooks, manuals, how-to books and similar reference works, but which has yet not been discussed fully in a lexicographical context (Tarp 2008c: 126). However, though the explanation of crawl is useful for operation, it could also be argued that the explanation is written to serve a user in a cognitive situation: If the dictionary is designed to help a user looking for information out of curiosity, the dictionary has a cognitive function, but if it is designed to help a user 
perform an act, the dictionary has an operative function. This, however, has not been specified in the introduction.

In the introduction, Dictionary 44 mentions that it among other things wants to explain how to do something, e.g. how to lose weight, i.e. one of its functions is the operative function. For the lemma overweight, the user is informed that in order to lose weight, $\mathrm{s} /$ he will have to participate regularly in physical activity and eat a healthy diet. Though neither this explanation nor the one of crawl are formulated with imperatives (which is the typical linguistic form of instructive texts, cf. Nielsen (2006: 15-16)) as in the case of press-up, these could still work as instructions because the purpose of these explanations is to help people find information about how to do something.

In terms of the relevant users, the operative function entails an expanded user typology, cf. Section 2.1, since for operation, the focus is also on skills, cf. Tarp (2008a: 153-159). Thus, we cannot simply talk about layman, semi-expert and expert, but should incorporate the following types of athletes: beginner, possibly also intermediate, and advanced. However, users in an operative situation are not only characterised by their skills, but (potentially) also according to their specialised (technical) knowledge. A person may for example be skilled in weightlifting, but not have much knowledge about the body's reactions to weightlifting, or he may be both skilled and have knowledge about the field. In terms of the data types wanted for this situation and the characteristics of these users, no answers have yet been provided in meta-lexicography. But for example, the explanation of the lemma press-up suggests that an article in an operative dictionary should not only consist of an instructive explanation, but possibly also other data types such as "variants" and "common mistakes", presumably especially for beginners 5 .

\subsubsection{The interpretative function}

Both Dictionaries 18 and 21 incorporate as part of the back matter descriptions of referee signals in different sports (e.g. basketball) in the form of illustrations. These non-linguistic signs support what in the function theory has been called the interpretative function, cf. Tarp (2008b: 185) who writes that "[r]ecently, it has been discussed whether there is a fourth main user situation, the interpretive one, where the user needs to interpret signals and symbols in the surrounding world, but it is still too early to conclude anything in this respect." Though these visual data are not part of the central list, but are outer texts, the dictionaries appear to have a secondary interpretative function. In Dictionary 18, the images are supplemented by text explaining what the referee is doing and also what this movement means. As in the case of Point 2 with the discussion of the lemma red card, the lexicographers have also here only incorporated the referee signals in the most popular sports. Other less popular sports such as handball and volleyball have not been included. 
Figure 2: Referee signals in Dictionary 18

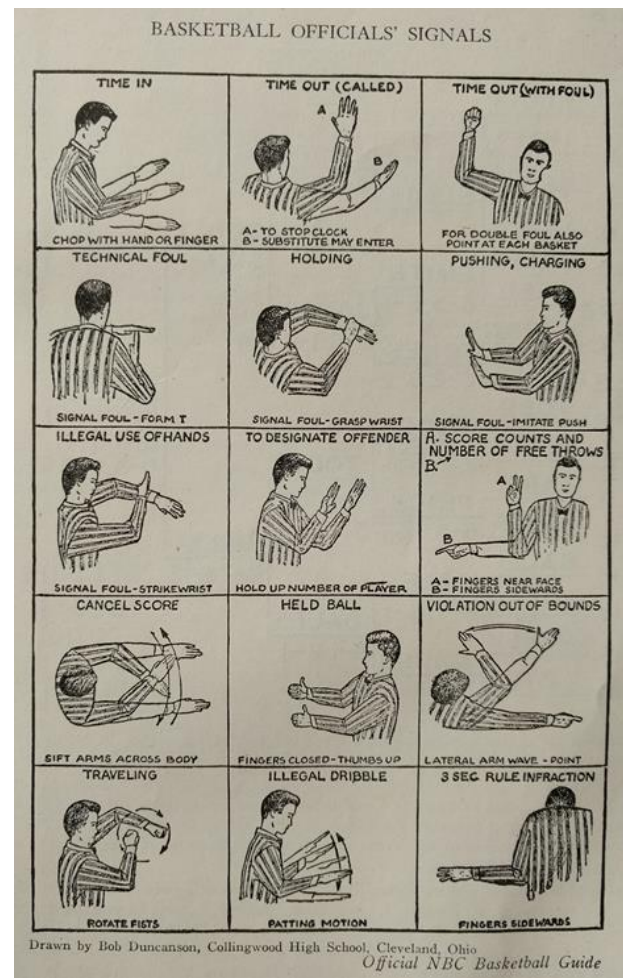

Figure 3: Referee signals in Dictionary 21

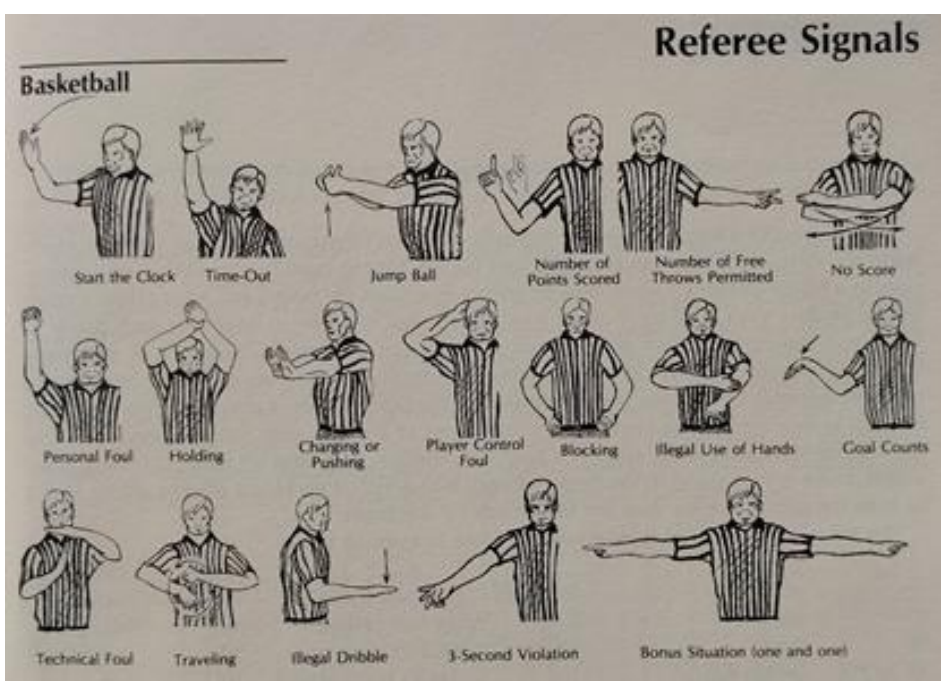


Some interesting questions related to research of the interpretative function are for example how such an explanation should be formulated and how the search options in an e-tool with an interpretative function should work. For example, in the above illustrations from Dictionary 21, for the signal time-out, a cross-reference to the lemma time-out in the central word list could have been made, thus giving the user a more thorough description, and which would turn this dictionary component into an integrated dictionary component, cf. Nielsen (2006: 8). In an e-tool, separate articles could be made of each signal so the user could more easily search for a certain signal e.g. using a photo in the search field or applying keywords in the search field. If the same signal is used across different sports, then the signal could be called polysemous (though not everyone would agree with this use of the term polysemous), and different descriptions of this signal should be provided. A suggested article for an interpretative information tool is provided below. In this suggestion, the meaning explanation is preceded by a description of the sign (hand signal), though this part of the article is not compulsory as some non-linguistic signs are almost indescribable.

\section{Volleyball}

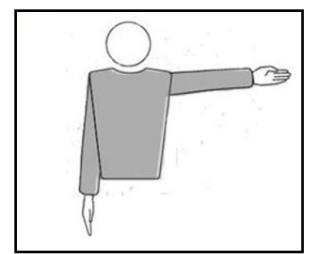

Hand signal: Arm extended towards the serving team

Explanation: The serving team is requested to put the ball in play

The above-mentioned referee or umpire signals are as mentioned attached in the dictionaries as outer texts, but this is not the case for Dictionary 25, in which these different types of signals are presented in the articles for each different sport (the lemma list only consists of branches of sport), e.g. in baseball, basketball, ice hockey and lacrosse. In Dictionary 21, the lemma flag is divided into 5 polysemes, of which the first corresponds to the use in racing, "Any of a series of flags of different colors used to signal the competitors on the course in motor racing and yacht racing"; this text is on the opposite page supplemented by images of the different flags used in yacht racing, each flag supported by a text that briefly describes what the flag looks like and how it should be interpreted. Thus, it is possible to find data that support an interpretative function both in the central lists and in the outer texts. However, as in Section 2.4.1 where the function of the dictionary could either be cognitive or operative, it could also be argued that in the case of referee signals, the function could instead be operative; e.g. if a basketball referee is interested in learning how to signal time-out, he will search in an operative dictionary and be provided with somewhat the same data.

For most of the mentioned dictionaries, the analysed data were most likely not included with the aim of creating interpretative and operative dictionaries, 
but the data point to the fact that even though these functions have not been discussed in meta-lexicography, they are actually applied in practical lexicography.

\section{A functional approach to meaning explanations}

It is not a surprise that it is possible to find different meaning explanations in different dictionaries, and some of the investigated explanations seem to have been produced according to a specific user type. However, many have not been produced properly according to the user situation, though this was for example suggested by Nielsen $(2011,2013)$; as shown in Table 1, in many cases, the user situation is not even specified in the introduction.

Many contributions on lexicographical meaning explanations comment on the form of the meaning explanation, e.g. that it should be formulated using a sentence definition, analytical definition or folk definitions (see e.g. MacFarquhar and Richards (1983), Stock (1988) and Wingate (2002)), and in terms of the content, they argue that the word must neither be over- or underspecified and that it should contain semantic data, not encyclopaedic data. The discussion concerning encyclopaedic and semantic data is not new, cf. e.g. Haiman (1980), Wierzbicka (1992), Bergenholtz and Kaufmann (1996) and Bergenholtz and Agerbo (2014a), of which the latter argue that in lexicography, it is not relevant to formulate a clear-cut boundary between semantic and encyclopaedic knowledge because the goal for a lexicographer is to identify and select meaning items as well as identify, select and distribute semantic components that can solve the needs of the potential dictionary user in a specific type of extra-lexicographical user situation. Thus, when we decide what and how much data to incorporate into a meaning explanation, it is the function and not the semanticencyclopaedic relation that is the crucial factor. This is demonstrated with some general suggestions below (this is not an exhaustive list):

1. An interested layman wants to know more than s/he already knows about a certain word or theme for a school paper and therefore looks this up in a cognitive dictionary (= cognition).

Requires: A much more elaborate meaning explanation than for reception. This could be solved with a lexical note that elaborates on the meaning explanation of the lemma from the reception dictionary, i.e. the lexicographer can show these two together in the cognitive dictionary instead of writing a different meaning explanation.

2. A layman is reading a text and looks up a word in order to understand its meaning in this specific text (= reception). There are two situations: A) The reader has seen or heard the word before, but is not quite sure what it means, or the reader thinks $\mathrm{s} /$ he can deduce the meaning from the con- 
text, but s/he wants the meaning verified; B) The reader has never come across the word before and cannot deduce its meaning from the context.

Requires: A) A short explanation that verifies what the user thinks the word means. This should only be a short sentence and no details are needed.

B) A rather elaborate meaning explanation; the reader should be able to understand the meaning of the word in the given context. A general meaning explanation is not very useful factual and cultural details are important.

3. A semi-expert is reading a text and looks up a word in order to understand its meaning in this specific text (= reception).

Requires: A much more detailed meaning explanation than the one provided for the layman. A semi-expert has specialised knowledge and is therefore interested in the finer details and is able to understand these.

4. A layman or semi-expert is writing a text and wants to check the inflection of a certain word so $\mathrm{s} /$ he uses a spelling and grammar dictionary (= production). This dictionary should contain meaning explanations in case of homonymy as the user needs to be able to distinguish between the homonyms if the dictionary applies grammatical homonymy.

Requires: Only a synonym if the person knows something about the relevant theme, but sometimes relevant synonyms do not exist; in the latter case, a simple meaning explanation will suffice, e.g. a short phrase.

5. A layman or semi-expert is writing a text and wants to use a synonym for a certain word so $\mathrm{s} /$ he uses a synonym dictionary (= production). There are two situations: A) The word is monosemous; B) The word is polysemous.

Requires: A) No explanation is needed.

B) A short sentence that makes it clear what the difference is between the two or more meanings of the word.

6. A layman (A) cannot remember or (B) does not know the word $\mathrm{s} /$ he is looking for when writing a text, but $\mathrm{s} /$ he knows its meaning (= production). For this purpose, a dictionary can be made in which the user can search for the word using Boolean operators and key search terms.

Requires: A meaning explanation that can help him/her decide on the right word (if it exists) in the result list.

(A) A short explanation is enough as the user already knows the word.

(B) The explanation should be as elaborate as for reception since the user is not familiar with this word. 
7. A person is working on a translation and looks up an unknown word from the source text in a bilingual dictionary in order to find an equivalent (= translation). There are two situations: A) The person is not an advanced L2-speaker and does not know much about the relevant theme; B) The person is an advanced L2-speaker and knows a lot about the relevant theme:

Requires: A) A rather detailed meaning explanation so the translator knows exactly which equivalent to use if there are more than one equivalent. The explanation should be supplied in both L1 and L2.

B) Only equivalents should be supplied as the person has sufficient knowledge to distinguish between the equivalents without the help of meaning explanations.

8. A beginner is not sure how to do a certain physical exercise and therefore looks the word up in a dictionary in order to get an instruction on how to carry out this exercise (= operation).

Requires: The explanation should briefly state what kind of exercise this is, and then it should describe in detail, step by step, what the person should do. This explanation should also include variations of and common mistakes connected to this exercise.

9. A person is in a situation where $\mathrm{s} /$ he does not understand what a street sign means and therefore does not know how to act in the situation (= interpretation). Therefore, $\mathrm{s} /$ he looks the sign up in a dictionary. There are two ways of searching: A) using search terms; B) searching with a photo of the sign.

Requires: A detailed description of the non-linguistic sign as the user's search words will be matched with the words in the explanation. The explanation must also include a description of how the person should act according to this sign as this is what is needed to solve the problem in the situation. In addition to a written explanation, the article should also contain a photo or an illustration, as the user in situation B will make a search with a photo, hoping to find an image in the database that matches it.

This overview shows (1) that many different explanations can and should be made according to the dictionary function. If we look at Dictionaries 6 and 42, these two general dictionaries actually present different explanations - but they do not explain the reason for providing different explanations, nor is it optimal that different types of explanations are shown in the same article, see e.g. the lemma aerobics in both of these online dictionaries. Their distinction made between simple/primary and full definitions is also sometimes non- 
existent, resulting in two similar explanations, e.g. pull-up in Dictionary 42. The overview also shows (2) that no distinction can or should be made between semantic and encyclopaedic knowledge in the selection and distribution of data - such a distinction should not be the factor determining the selection of semantic components. The lexicographer must always consider what types of data are relevant according to the dictionary function, not whether these are semantic or encyclopaedic. From this, we can extract the following functionbased definition of the term lexicographical meaning explanation:

Lexicographical meaning explanation: A description in the form of one or more words, a sound, a video and/or an image of a word, phrase, idiom, collocation or some other language construction or of a non-linguistic sign, which is presented in a dictionary article, and which has been formulated, drawn or recorded to help satisfy the need of a specific user type in a specific extra-lexicographical user situation. The selection of semantic components and their organisation in the explanation is also based on the user and user situation.

If we look at the explanations above in the case of the interpretative and operative functions, these appear to be different than the other types of explanations. In the case of the operative function, the article of press-up in Dictionary 27 and the article of crawl in Dictionary 18 contain a short introductory explanation of the lemma and then a description of the moves. In the case of the interpretative function, Figure 2 shows that each signal is connected to an explanation (or a description) of the signal and an explanation of its meaning. Thus, we are actually working with three different types of overall lexicographical explanations:

1. Meaning explanation

2. Instructive explanation (or operative explanation)

3. Non-linguistic sign explanation (or interpretative explanation)

Thus, all major functions - communicative, cognitive, operative and interpretative - apply a certain type of meaning explanation (as shown above, there are many different types of meaning explanations), and in addition, the operative dictionary applies an instructive explanation and the interpretative dictionary sometimes incorporates a non-linguistic sign explanation. I.e. (8) and (9) should be revised:

8'. A beginner is not sure how to do a certain physical exercise and therefore looks the word up in a dictionary in order to get an instruction on how to carry out this exercise (= operation).

Requires: A short meaning explanation in the form of a sentence (not as elaborate as for reception) + an instructive explanation.

9'. A person is in a situation where he does not understand what a sign in the street means and therefore does not know how to act in the situation (= interpretation). 
Requires: In some cases a non-linguistic sign explanation + a meaning explanation telling what the sign indicates and how one should react to it. Of course, the sign should also be represented nonverbally.

These definitions of lexicographical explanations are relevant both for general and specialised dictionaries as the basis for these concepts is not the content of a dictionary, but the function. In addition, this functional approach to meaning explanations is much more flexible and dynamic as sought after by Nielsen (2011), i.e. a meaning explanation should not be made as a one-size-fits-all, but according to the given function. A number of different explanations of the same lemma could thus be included in the same database and extracted for the different dictionaries produced from this database.

\section{Concluding remarks}

The study presented in this paper has highlighted the often occurring inadequacy of meaning explanations of terms both in general and specialised information tools. This was demonstrated by comparing the stated function of each dictionary to a number of selected explanations in the dictionary. Based on these findings, it is suggested how specialised words or multi-word constructions in future dictionaries should be treated. As the approach applied in this study has been deduction, a next step would be to test these suggestions on dictionary users.

\section{Endnotes}

1. In Denmark, there are today two competing online dictionaries of contemporary Danish: Den Danske Ordbog and Den Danske Netordbog. Because the author of this paper works as an editor on the latter, this dictionary has been discarded in the study.

2. Though throughout this paper the term dictionary is often applied, it could be replaced by the broader term information tool.

3. See Section 2.4.1 for further comments on this new user type termed beginner.

4. See Section 2.4.1 for further comments on this new user type termed advanced.

5. The operative function in a sports setting is currently being investigated by this author by filming different sports teams during training and fitness classes with the aim of identifying the information and questions exchanged between trainers/instructors and their members, converting this into data types. The same approach was followed by Patrick Leroyer (personal communication) in the production of OENOLEX Burgundy, a French monolingual online wine dictionary; see Leroyer and Høy (2013). 


\section{References}

Agerbo, H. 2015. How to Describe Sports Terms in Information Tools for Laymen. Estudios de Lexicografia: $137-160$.

Béjoint, H. 2015. Dictionaries for General Users. Durkin, P. (Ed.). 2015. The Oxford Handbook of Lexicography: 7-24. Oxford: Oxford University Press.

Bergenholtz, H. and H. Agerbo. 2014a. Extraction, Selection and Distribution of Meaning Elements for Monolingual Information Tools. Lexicographica 30: 488-510.

Bergenholtz, H. and H. Agerbo. 2014b. Meaning Identification and Meaning Selection for General Language Monolingual Dictionaries. Hermes. Journal of Language and Communication in Business 52: 125-139.

Bergenholtz, H. and I. Bergenholtz. 2011. A Dictionary is a Tool, a Good Dictionary is a Monofunctional Tool. Fuertes-Olivera, P. and H. Bergenholtz (Eds.) 2011. e-Lexicography: The Internet, Digital Initiatives and Lexicography: 187-207. London/New York: Continuum.

Bergenholtz, H., T.J.D. Bothma and R.H. Gouws. 2015. Phases and Steps in the Access to Data in Information Tools. Lexikos 25: 1-30.

Bergenholtz, H. and U. Kaufmann. 1996. Enzyklopädische Informationen in Wörterbüchern. Weber, N. (Ed.). 1996. Semantik, Lexikographie und Computeranwendungen: 167-180. Tübingen: Max Niemeyer.

Bergenholtz, H. and U. Kaufmann. 1997. Terminography and Lexicography. A Critical Survey of Dictionaries from a Single Specialised Field. Hermes. Journal of Linguistics 18: 91-125.

Bergenholtz, H. and S. Tarp (Eds.). 1994. Manual i fagleksikografi: udarbejdelse affagordbøger — problemer og løsningsforslag. Herning: Systime.

Bergenholtz, H. and S. Tarp. 2003. Two Opposing Theories: On H.E. Wiegand's Recent Discovery of Lexicographic Functions. Hermes. Journal of Language and Communication Studies 31: 171-196.

Diab, T. 1990. Pedagogical Lexicography. A Case Study of Arab Nurses as Dictionary Users. Tübingen: Max Niemeyer.

De Schryver, G.-M. and D.J. Prinsloo. 2011. Do Dictionaries Define on the Level of Their Target Users? A Case Study for Three Dutch Dictionaries. International Journal of Lexicography 24(1): $5-28$.

Fuertes-Olivera, P.A. and S. Tarp. 2014. Theory and Practice of Specialised Online Dictionaries: Lexicography versus Terminography. Berlin/Boston: De Gruyter.

Gouws, R.H. and S. Tarp. Forthcoming. Information Overload and Data Overload in Lexicography. International Journal of Lexicography 29.

Haiman, J. 1980. Dictionaries and Encyclopedias. Lingua 50(4): 329-357.

Hashimzade, N., G.A. Myles and G.D. Myles. 2014. Can Authority be Sustained while Balancing Accessibility and Formality. Hermes. Journal of Language and Business Communication 52: 11-24.

Leroyer, P. Forthcoming. Dictionaries for Text Reception. Fuertes-Olivera, P.A. (Ed.). Forthcoming. The Routledge Handbook of Lexicography. Oxfordshire: Routledge.

Leroyer, P. and A. Høy. 2013. Vinsmagningsordbogen Oenolex Bourgogne. En milepæl i pragmatisk fagleksikografi. Nordiske Studier i Leksikografi 12: 287-302.

Lew, R. 2013. Identifying, Ordering and Defining Senses. Jackson, H. (Ed.). 2013. The Bloomsbury Companion to Lexicography: 284-302. London: Bloomsbury.

Lombard, F.J. 1991. Die aard en aanbieding van die leksikografiese definisie. Lexikos 1: 158-182. 
MacFarquhar, P.D. and J.C. Richards. 1983. On Dictionaries and Definitions. RELC Journal 14(1): 111-124.

Meyer, I. and K. Mackintosh. 2000. When Terms Move into our Everyday Lives: An Overview of De-terminologization. Terminology 6(1): 111-138.

Morris, W. (Ed.). 1985. The American Heritage Dictionary. Boston: Houghton Mifflin.

Nesi, H. 2013. Researching Users and Uses of Dictionaries. Jackson, H. (Ed.). 2013. The Bloomsbury Companion to Lexicography: 62-74. London: Bloomsbury.

Nielsen, S. 1990. Lexicographical Macrostructures. Hermes. Journal of Language and Communication in Business 4: 49-66.

Nielsen, S. 2006. A Functional Approach to User Guides. Dictionaries: Journal of the Dictionary Society of North America 27: 1-20.

Nielsen, S. 2008. The Effect of Lexicographical Information Costs on Dictionary Making and Use. Lexikos 18: 170-189.

Nielsen, S. 2010. The Relevance of Lexicographic Functions. Aminova, A. and N. Fattakhova (Eds.) 2010. Comparative Philology and Multilingualism. Materials of the International Scientific Conference: 132-135. Kazan: Tatar Academy of Science.

Nielsen, S. 2011. Function- and User-related Definitions in Online Dictionaries. Kartashkova, F. (Ed.). 2011. Ivanovskaya leksikografischeskaya shkola: traditsii i innovatsii: 197-219. Ivanovo: Ivanovo State University.

Nielsen, S. 2013. The Future of Dictionaries, Dictionaries of the Future. Jackson, H. (Ed.). 2013. The Bloomsbury Companion to Lexicography. London: Bloomsbury.

Nielsen, S. and R. Almind. 2011. From Data to Dictionary. Fuertes-Olivera, P. and H. Bergenholtz (Eds.). 2011. e-Lexicography: The Internet, Digital Initiatives and Lexicography: 141-167. London/New York: Continuum.

Rull, A.N. 2003. La terminología del deporte en los diccionarios generales del español. Revista de Lexicografia 9: 57-95.

Stock, P. 1988. The Structure and Function of Definitions. Snell-Hornby, M. (Ed.). 1988. ZüriLEX '86 Proceedings. Papers Read at the EURALEX International Congress, University of Zürich, 9-14 September 1986: 81-90. Tübingen: Francke Verlag.

Tarp, S. 2008a. Lexicography in the Borderland Between Knowledge and Non-knowledge: General Lexicographical Theory with Particular Focus on Learner's Lexicography. Aarhus: Aarhus School of Business, Centre for Lexicography.

Tarp, S. 2008b. Revival of a Dusty Old Profession. Hermes. Journal of Language and Communication Studies 41: 175-188.

Tarp, S. 2008c. The Third Leg of Two-legged Lexicography. Hermes. Journal of Language and Communication Studies 40: 117-131.

Van der Merwe, M.F. and P.A. Fuertes-Olivera. 2014. The Influence of the User Needs Paradigm in Specialised Lexicography: Some Reflections in Connection with Two South African Wine Dictionaries. Ibérica: Revista de la Asociación Europea de Lenguas para Fines Específicos 27: 77-96.

Wierzbicka, A. 1992. What are the Uses of Theoretical Lexicography? Dictionaries: Journal of the Dictionary Society of North America 14: 44-78.

Wingate, U. 2002. The Effectiveness of Different Learner Dictionaries: An Investigation into the Use of Dictionaries for Reading Comprehension by Intermediate Learners of German. Tübingen: Max Niemeyer. 


\section{Addendum}

\section{English general dictionaries}

1. Cambridge Advanced Learner's Dictionary online

2. Collins English Dictionary online

3. Collins COBUILD Advanced Dictionary of English online

4. Longman Dictionary of Contemporary English online

5. Macmillan Dictionary

41. Merriam Webster Learner's Dictionary

6. Merriam-Webster

7. Webster's Third New International Dictionary

online

online

8. Oxford Learner's Dictionaries

online

9. Oxford Dictionaries

paper, 1986

online

10. The American Heritage Dictionary

online

11. Harrap's Essential English Dictionary

paper, 1985

42. Vocabulary.com

paper, 1995

online

\section{Danish dictionaries: one sports dictionary, four general dictionaries}

12. Dansk Sportsleksikon 1-2

13. Ordbog over det danske sprog

14. Den Danske Ordbog 1-6

15. Politikens Nudansk ordbog med etymologi

16. Gyldendals dansk-dansk ordbog

\section{English sports dictionaries}

17. Encyclopedia of sports

18. The Dictionary of sports

19. Dictionary of Sports

20. The Oxford companion to sports \& games

21. Webster's Sports dictionary

22. The Complete Sports Dictionary

23. The Macmillan dictionary of sport and games

24. (The facts on file) Dictionary of Fitness

25. What's What in Sports

26. A Dictionary of Sports Injuries and Disorders

27. Food and Fitness: Dictionary of Diet and Exercise

43. Sports: The complete visual reference

44. The encyclopedia of exercise, sport and health

28. Academic Dictionary of Sports

29. Dictionary of Sport and Exercise Science paper, 1944-1945

online

online + paper,

2004-2005

paper, 2010

paper, 1992

paper, 1944

paper, 1949

paper, 1961

paper, 1975

paper, 1976

paper, 1979

paper, 1980

paper, 1984

paper, 1984

paper, 1996

online + paper,

1997

paper, 2000

paper, 2004

paper, 2005

paper, 2006 
30. Dictionary of Sports and Games terminology

paper, 2010

31. A Dictionary of Sports Studies online + paper,

32. Visual Dictionary (Merriam-Webster)

33. Sportsdefinitions.com

2010/2016

online

online

\section{English subfield dictionaries}

34. The concise dictionary of tennis

paper, 1978

35. A dictionary of the Martial Arts

paper, 1991

36. Visual Dictionary of baseball

paper, 2001

37. Running Encyclopedia

paper, 2002

38. Now $110 \%$ complete football lexicon

paper, 2006

39. Cricket Lexicon

paper, 2006

40. Bendelow \& Kidd's Dictionary of Football

paper, 2015 